\title{
Vermicomposting in Turkey: Challenges and opportunities in future
}

\author{
Korkmaz Bellitürk \\ Namık Kemal University, Faculty of Agriculture, Department of Soil Science and Plant Nutrition, Tekirdağ/Turkey \\ E-mail: kbelliturk@hotmail.com
}

\begin{abstract}
Turkey has been undergoing positive agricultural transformations since the 2011. Its agricultural sector today is developing new techniques and products. One of the best examples of this is the production of vermicompost and its use in agriculture. Turkey is on both Asian and European continents (Eurasia) with approximately 81 million people. Turkey has 24 million hectares of agriculture land (excluding pastures+ meadows, including total arable land and under permanent crops). However, there is little data available on vermicompost production in Turkey. The production of vermicompost started after 2011. The average solid vermicompost production in 2017 was about 20000 tonnes produced by 15 plants with official production permits by the Republic of Turkey Ministry of Agriculture and Forestry. New legislation in Turkey published in legislative review no 30341 in February 2018 regulates the industry. Turkey aims to be among the top three producers of this fertility amendment by 2023. In addition to the officially sanctioned operations, there are approximately 4200 unauthorized vermicompost producers in Turkey. Interest in and production of vermicompost is likely going to increase. Research showed that there are many positive effects on soil quality and plant growth, although the mechanisms by which it improves the soil-plant systems are not yet fully understood. The use of vermicompost is important for the sustainability of agriculture. The main aim of the paper is to demonstrate and share reasonable causes for the increased interest in vermicompost and earthworms.
\end{abstract}

Keywords: Agriculture, soil, waste, earthworm, vermicompost.

\section{Introduction}

Turkey is one of the few countries in the world that is self-sufficient in terms of agricultural food. The country's water resources, fertile soils, high agricultural technologies, determined farmers; all are contributing for a successful agricultural sector. However, organic matter levels of agricultural soils are gradually decreasing and the industry is relying on synthetic fertilizers and pesticides (Bellitürk and Sağlam, 2005). These can adversely affect soil quality and environment. Judicial use of chemical fertilizer is used based on soil fertility analyses can ameliorate the environmental effects. Vermicompost, an organic amendment, may help rehabilitate lands on small farms currently affected by adverse environmental conditions or off-set the high cost associated with chemical fertilizers, pesticides and oil in some parts of Turkey. Some of the main problems in Turkey's agro ecosystems are insufficient organic matter, changes in soil $\mathrm{pH}$ values, soil salinity and misuse of agricultural and converted forest land. By replacing chemical fertilizers with vermicompost organic matter may be built and $\mathrm{pH}$ may increase. Additional benefits of vermicompost include the disease resistance and avoiding early season deficiencies that are sometimes observed in organic agriculture (Bellitürk and Bağdatl1, 2016). 
As it is well known that chemical fertilizers are playing vital role for higher agricultural production. In Turkey, both production and use of this fertilizer are increasing day by day (Bellitürk et al., 2017b; Bellitürk, 2018). However, in the present scenario the overuse of fertilizers is posing environmental problems which are often difficult to overcome in developing countries (Sutton et al., 2011; Sun et al., 2012; Bellitürk, 2017). Vermicompost is now often presented as an attractive alternative to chemical fertilizers (Bellitürk et al., 2015; Bidabadi et al., 2016; Mengistu et al., 2017; Bellitürk et al., 2017a; Y1lmaz and Bellitürk, 2018). At the larger scale of regional food systems, fertilizing with vermicompost means recycling nutrients in food waste, agricultural and industrial wastes that would otherwise be taken to landfills. Compost can thus reduce chemical fertilizer use. The increasing cost of chemical fertilizers has prompted farmers in Turkey to rethink their soil fertility practices. New, improved practices will include vermicompost (Bellitürk et al., 2017b).

The organic waste management has improved in Turkey. The number of conventional composting plants has increased since 2000 and the number of vermicomposting plants has increased since 2010 in Turkey (Bellitürk, 2018). An example is the Aegean Region and Marmara Region. There is an increasing number of unregulated composting/vermicomposting operations, estimated at over 4500, that may represent a risk to soils and groundwater. The vast majority of these small scale operations (approximately 95\%) are small scale vermicompost producers. There are only fifteen regulated and legally authorized vermicomposting plants, the number of plants that produce legally authorized vermicompost is only 15 at present. This number needs to increase for Turkey to become a leading producer of vermicompost by 2023 (Bellitürk, 2018).

The amount of solid vermicompost increased from 5000 tonnes in 2015 to about 20000 tonnes in 2017 by legally authorized plants despite the lack of academic research on this subject. The number of academic studies in this field is also increasing nowadays. Namık Kemal University has great contribution to this subject in Turkey. According to the data obtained, solid and liquid vermicompost have been successfully used to improve yield and quality of crops, vegetables, fruits and landscape plants (Görres and Bellitürk, 2012; Açıkbaş and Bellitürk, 2016; Zahmacıoğlu et al., 2017; Açıbaş and Bellitürk, 2017; Barlas and Bellitürk, 2017). Vermicompost can be called the "Second Green Revolution" by completely replacing the destructive agrochemicals (Sinha et al., 2010).

"Vermicomposting-Vermitechnology-Vermiculture Movement" has multiple objectives in Turkey. These include organic waste (especially animal wastes) management, and improved sustainability of agricultural production.

The objective of the present research is to evaluate the vermicompost sector in Turkey nowadays. Another aim of the research is to show why the interest in vermicompost has been increasing day by day in Turkey.

\section{What exactly are Vermicompost and Vermicomposting?}

"Vermi" is the Latin for "worm". Vermicompost (worm manure) is a nutritive organic fertilizer which must be used for fertilizing as an agricultural input. Vermicomposting (worm composting) is a biological process. Vermicomposting research focuses on the feedstock selection and effect on plant growth, not only in Turkey but also worldwide (Bellitürk, 2017; Bellitürk, 2018). Vermicompost is an important slow-release organic fertiliser for protection of Turkey agricultural soils. In contrast, vermiculture focuses on the worms themselves, and promotes the production of worm biomass maybe for sale as feed for animals or for sale to new vermicomposting operations. Different livestock animals 
and fishes have shown excellent production success when fed with vermi-meal or earthworm meal (Guerrero, 2009). Vermitechnology is a promising technique for organic waste recycling.

Vermicompost is a nutrient-rich, earthy-smelling, microbiologically-active organic amendment that results from the interactions between earthworms and microorganism during the gut passage of organic matter (Dominguez, 2004). However, the nutrient and humus content of solid vermicompost is variable. Vermicompost produced legally in Turkey was found to have high nutrient content as shown in Table 1 (Bellitürk, 2018). It was found that there was excellent plant growth as well as improved marketable yield in many crops (Yan et al., 2013; Açıkbaş and Bellitürk, 2016; Zahmacıŏlu et al., 2017; Açıkbaş and Bellitürk, 2017; Barlas and Bellitürk, 2017; Bellitürk et al., 2017b). Vermicompost reduces pollution by providing a valuable substitute for chemical fertilizers (Karmakar et al., 2012) and releasing its nutrients slower than synthetic fertilizers. The value of a vermicompost can be based both upon its nutrient and organic matter content. According to Edwards (1995), biological activity of useful microorganisms in vermicompost is 10 to 20 times greater than that of soil. Vermiculture is the process of culturing earthworms, especially for the purpose to convert organic waste into fertilizer.

Table 1. Agrochemical (or nutrient) compositions of food, cow and sheep waste vermicompost (solid) which is produced in Turkey (on averages in the country).

\begin{tabular}{lccc}
\multicolumn{1}{c}{$\begin{array}{c}\text { Nutrient elements and some } \\
\text { other contents }\end{array}$} & $\begin{array}{c}\text { Food waste } \\
\text { vermicompost }\end{array}$ & $\begin{array}{c}\text { Cow manure } \\
\text { vermicompost }\end{array}$ & $\begin{array}{c}\text { Sheep manure } \\
\text { vermicompost }\end{array}$ \\
\hline Nitrogen $(\%)$ & 1.95 & 1.75 & 1.60 \\
Phosphorus (\%) & 1.73 & 1.01 & 0.41 \\
Potassium (\%) & 1.32 & 0.74 & 0.37 \\
Calcium (\%) & 2.35 & 2.80 & 2.18 \\
Magnesium (\%) & 0.62 & 0.98 & 1.06 \\
Zinc (\%) & 0.035 & 0.043 & 0.041 \\
Manganese (\%) & 0.09 & 0.12 & 0.18 \\
Organic matter (\%) & 41.00 & 51.00 & 43.00 \\
EC (Soluble salts) (dS/m) & 4.60 & 6.85 & 8.46 \\
\hline
\end{tabular}

Vermicompost, contrary to conventional compost, is the product of an accelerated bio-oxidation of organic matter using epigeic earthworm populations without passing through a thermophilic stage (Dominguez et al., 1997). While mature compost may take as long as 6-8 months to produce, vermicompost produced with modern technologies can be ready in 3-4 months or less.

\section{Which Species of Earthworms?}

Earthworms improve soil fertility and significantly support agricultural productivity (Sinha et al., 2010). Shortly earthworms play an integral part in agriculture. Earthworms are classified into epigeic, endogeic and anecic species based on their ecological functions (Brown, 1995; Bhatnagar and Palta, 1996). Epigiec species live at the surface of the soil, usually in organic matter rich horizons (James and Guimaraes, 2011) of forest or pasture soils. These worms do not create burrows and cast at the soil surface. Endogeic earthworms live in the mineral soil and make horizontal burrows. The cast is mainly found under the ground. Anecic earthworms make deep, vertical burrows. They introduce organic wastes from the surface into their burrows. The best earthworm species for vermicomposting are epigeic. They are most suited for vermicomposting because they move into wastes newly applied at the top of earthworm bins, are usually very prolific in their reproduction, and are voracious feeders (Bouché, 1977). Epigeic earthworms have been bred since about 2010 for use in vermicompostingvermiculture in Turkey. Academic studies on the number and species of earthworm are still continuing in Turkey, although much of the earthworm studies focus on the taxonomy of earthworms in genera. 
Four species are used in Turkey: Eisenia fetida, Eisenia andrei, Dendrobaena venata, Lumbricus rubellus. Patil et al. (2018) reported that, between the two species of earthworms, Eudrilus euginae species of earthworm found superior over Eisenia foetida species of earthworm in respect of most of the parameters studied. However, the use of Eudrilus euginae species is not widespread in Turkey's vermicomposting industry. The most frequently used species of compost worm is the Eisenia fetida which is naturally predisposed towards high rates of reproduction and their bodies are more resistant than other species used in Turkey. They can also be obtained from some villages (in non-arid regions of the country) where vermicomposting is already being done.

\section{What are Common Vermicomposting Feedstocks Used in Turkey?}

Many organic wastes have been converted into vermicompost by different species of epigeic earthworms which include cow manure, cattle manure, horse waste, leaves, paper mill wastes, yard wastes, sheep-goat manure, sawn grass, prunings, forest product sawdust, commercial mulch, ground rice waste, tea-coffee wastes and other agricultural residues (Bellitürk et al., 2015; Bellitürk, 2016). There are a lot of studies on different livestock animals, and fishes have shown excellent results of feeding the animals with vermi-meal or earthworm meal (Guerrero, 2009). Turkish academicians and researchers are interested in this issue very much.

Many domestic, agricultural, and industrial organic waste can be used for vermicomposting. However, some wastes such as citrus, onion-garlic, and meat-bone should not be used for this purpose. The $\mathrm{pH}$ value of the earthworm feed is also very important. There is many organic waste products that can be used in vermicomposting in Turkey. The nuisance wastes have to eliminated and develop a valuable product in Turkey. Therefore, vermicompost represents an efficient and very important recycling for waste management in Turkey.

\section{High-Technology Vermicomposting Systems in Turkey}

Vermicompost may be produced using different technologies. The traditional open systems of vermicomposting have been based on beds, boxes or windrows on the ground containing materials up to 70-80 $\mathrm{cm}$ high and 1-2 m wide, but such methods have numerous drawbacks and are not efficient as well as posing potential pollution problems. Since epigeic earthworms a surface dweller which works in the upper layers of the soil (approximately $15-20 \mathrm{~cm}$ deep), the feedstock should not be piled higher than $60-70 \mathrm{~cm}$ deep (Bellitürk, 2018). The official regulation does not allow this. But the vast majority of vermicompost producers use this method. However, companies that produce vermicompost in Turkey according to the rules generally use modern machine system. There is increased interest in developing automated vermicomposting systems. Engineers at the Riverm Ltd. Company, Tekirdag province, a leading designer of efficient earthworm waste harvesting system, base their system on the principles of automated continuous flow reactors, also known as RHS (Fig. 1). RHS is generally $20 \mathrm{~m}$ long; $1.2 \mathrm{~m}$ wide, $60 \mathrm{~cm}$ deep and on a steel frame, with plywood or water resist material sides. These work automatically with electronic control units controlling (parameters of harvest, temperature, humidity). This system has been widely used in Turkey for 6 years and is officially certified in Turkey. Although this system leverages the ecology of epigeic earthworms and reduces the chance of pollution, it currently has a high price. Engineering research to reduce the price is currently conducted at Riverm Company. According to Edwards (2011a), academic and economic studies have shown that such reactors have more profitable economic potential to produce vermicompost than either windrows or ground bed systems. Legal arrangements also support production by these reactors in Turkey. 


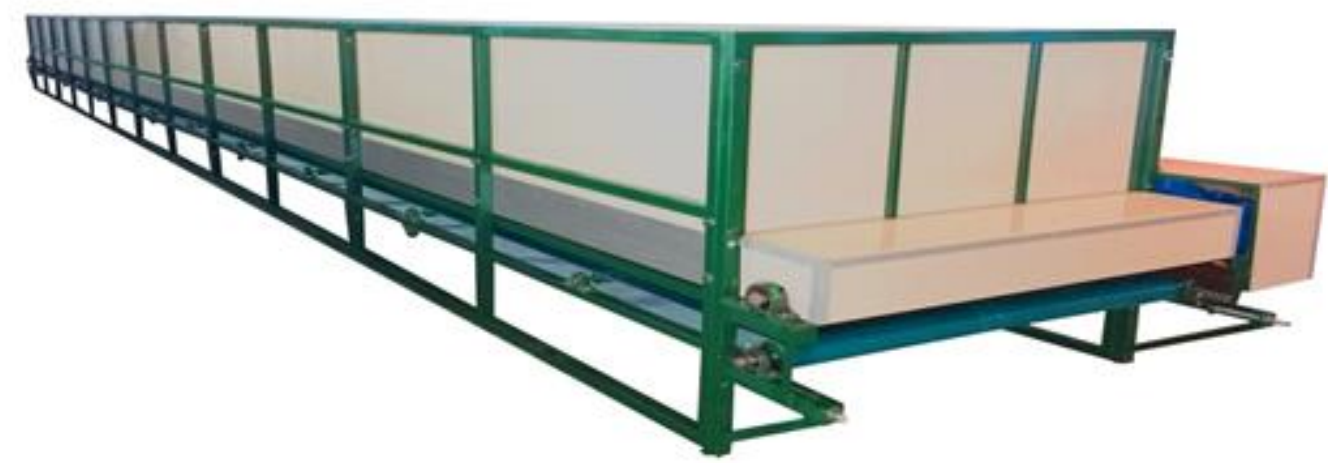

Figure 1. Automated continuous flow reactor system (RHS) developed by Riverm Company.

The system designed and developed by Riverm Company in Tekirdag province. This system is economically somewhat costly. In Turkey, finished vermicompost has to undergo a heat treatment with special devices if it is to be certified (Fig. 2). This is to ensure that the vermicompost is not to contaminate crops with pathogens (Bellitürk 2018). In other countries, heat treatment of feedstocks is applied prior to feeding the compost to the worms. This conserves the mesophilic microbial community that is thought to be essential for some of the functions of vermicompost.

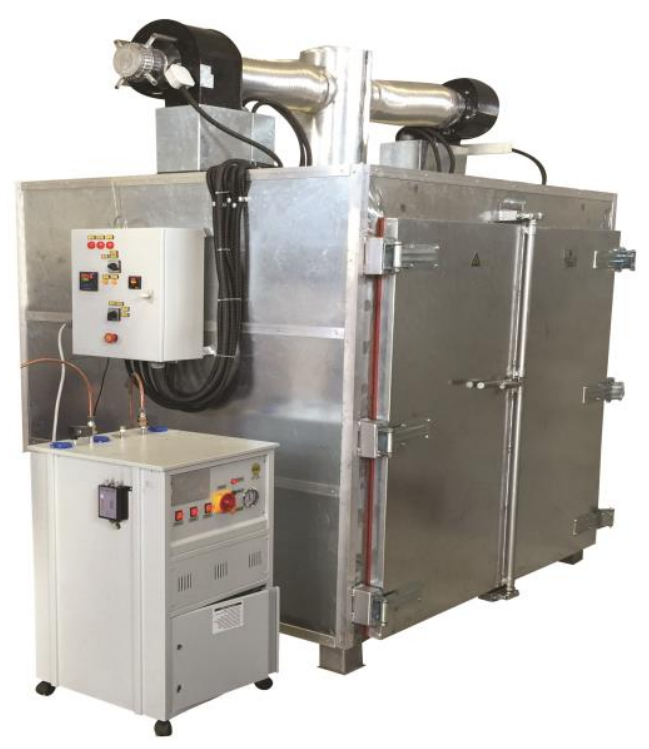

Figure 2. Heat treatment (sterilization) machine developed by Riverm Company, Turkey.

There are several methods of harvesting vermicompost in the country. In continuous flow reactors such as the one used at Riverm, the compost is harvested using a slicing knife at the bottom of the reactor. Usually $5 \mathrm{~cm}$ of vermicompost is removed. This bottom layer should not contain many epigeic worms as they tend to congregate at the surface. However, some worms are still found in the harvested layer. Because separating earthworms from the compost is laboriously but necessary (Edwards, 2011b), Riverm has developed a machine that simplifies the separation (Fig. 3). 


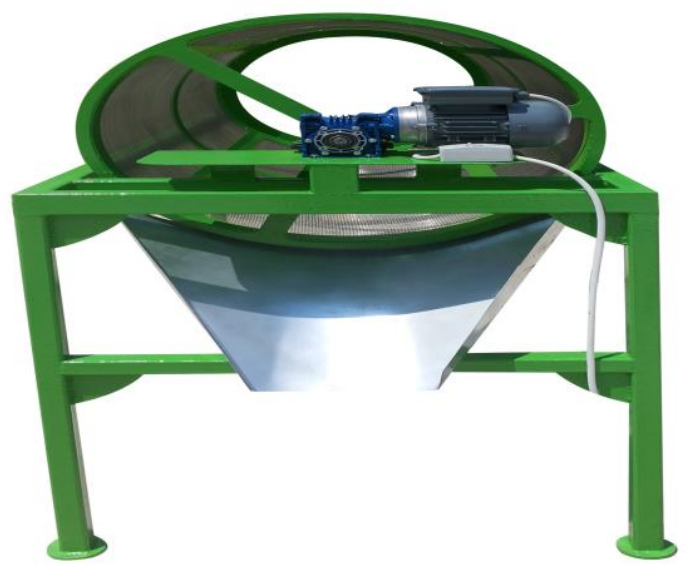

Figure 3. Rotating vermicompost separation system developed by Riverm Company, Turkey.

It is important to dry the vermicompost after the harvest so that it can be packaged stored and transported without it losing its fertility. Special ventilators are used for drying (Fig. 4). Finished compost should contain less than 35\% moisture which reduces transport cost and facilitates mechanical application.

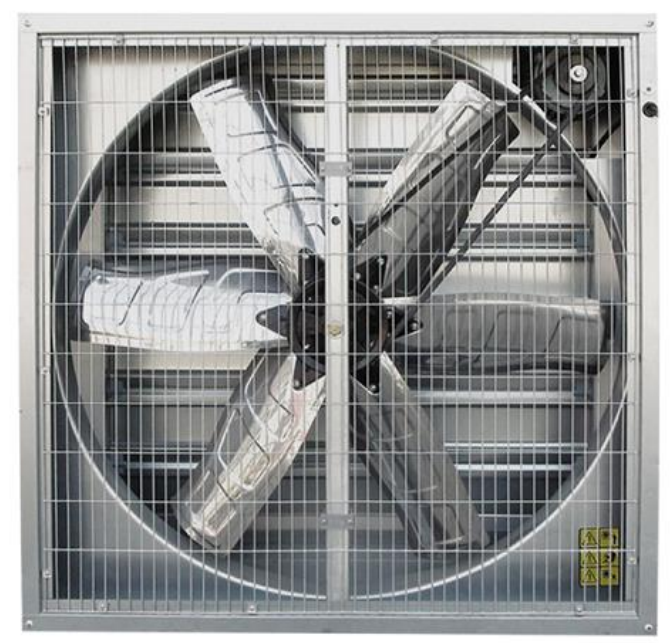

Figure 4. Ventilator for solid vermicompost drying.

\section{What is the Economic Position of the Vermicompost Sector in Turkey?}

This section provides an overview of the economic activity, employment and costs of the vermicompost sectors in Turkey in a favourable national context. There are not many academic studies on the economic value of the vermicompost in Turkey. However, the price of vermicompost vary considerably based on their technology, sterility, organic-waste sources, ranging through animal manures, domestic food wastes, and food technological wastes organic wastes (Arancon and Edwards, 2011). Solid vermicompost is currently sold at prices from about 2000 TL-3000 TL per ton in Turkey (TL: Turkish Lira). Liquid vermicompost sold at prices from about 25000 TL-60000 TL per ton in the country. Although, conventional compost is considerably cheaper, from about 1000 TL per ton, yield improvements are disproportionally higher with vermicompost due its high available nutrient density. Part of the economic equation is also the sale of excess worms. Some of these may be harvested from vermicomposting operations. However, some dedicated vermiculture operations also exist in Turkey. 
In spite of the relatively high price, the vermicompost market has been growing rapidly for 7 years with 15 plants operating legally in Turkey in 2018. The growth of vermicompost comes with considerable job creation in the sector. The number of jobs in the vermicompost industry varies depending on the company and the location of the plants. Employment in the vermicompost sector is now distributed across all regions.

According to the all economic calculations, the application of vermicompost to the crops, fruits and greenhouse vegetables are more profitable than conventional compost in Turkey conditions (Erdil and Bellitürk, 2017). Current prices of solid and liquid vermicompost are an important factor to consider in deciding the most appropriate vermicompost as well as correct application rates. Turkish farmers are more likely to adopt vermicomposting if the selling price of solid-liquid vermicompost in Turkey decreases. Farmers should consider, however, that the benefits of vermicompost are not only plant nutritional but that the disease resistance attributed to vermicompost reduces the cost of chemical pesticides as well.

The better yields obtained when vermicompost instead of regular compost is applied is likely due to the fact that vermicompost has greater nutrient densities than compost. Also, in contrast to traditional compost, nutrients in vermicompost become available more quickly. Its application also improves chemical, physical, microbiota and biochemical properties of the soil (Vivas et al., 2009). Vermicompost contains biochemical substances that promote plant growth, soil amendment and resistant against plant diseases (Noble and Coventry, 2005). However, for Turkish farmers, vermicompost price is still perceived as high even though studies have shown that it provides greater yield and better quality produce. As a solution to the problems, farmers who are using vermicompost should be encouraged by Turkish government. Vermicompost can also be sued in combination with other fertility amendments. Austin (2015) found that vermicompost as a part of a starter ix for seedlings can increase yields substantially. Greater acceptance of vermicompost by farmers may come with more education and an understanding that sustainable farming also protects the environment. Studies on fcrop responses to vermicompost application should also include economic evaluations such as cost -benefit analyses (Austin, 2015). Given the low organic matter content of Turkish soils, more organic fertilizers such as vermicompost should be applied to maintain soil quality.

\section{Conclusions}

Vermicompost is rich in organic matter, which plays a vital role in soil fertility, and contains all essential plant nutrients in sufficient proportions. Vermicompost products are suitable for large and small scale production, from commercial crop production to kitchen gardens. Its use may also benefit agroforestry systems such as tree nut production on forest commission land. The new concept and trend are "ecological agriculture" in Turkey. Agricultural productivity is also decreasing due to global warming. Building organic matter content in soils is one way of combating climate change. Ecological agriculture is also of great importance for reducing the adverse effects of global warming. Vermitechnology, vermiculture and also vermicomposting provides the best answer for ecological agriculture, which is synonymous with "sustainable agriculture".

Both chemical and also organic fertilizers are important tools for agricultural development in support of food security and for maintaining soil productivity. Worm farming is said to be the fastest growing agricultural industry in the country with economic benefits like job creation. Maintaining the expansion of the industry requires great effort and academic. Training courses for vermicompost producers and farmers have been regularly held at Namık Kemal University, Turkey for the last 2 years. Numerous scientific presentations are held in national and international congresses in this 
country. Increasing agricultural productivity of soils is a major target over the coming decades. This is especially the case for agricultural lands that are affected by reducing soil organic matter where the crop, vegetable and fruit yields remain relatively low. Vermicompost application might help soil and plant to overcome this problem. The effects of vermicomposting on soil, plant and environmental will be considered in more detail in the future studies. This study thus presents as assessment of the economic, environmental and future impact of the sector, in terms of sustainable agricultural activity.

\section{Acknowledgements}

The author is grateful to the anonymous reviewers for their constructive comments on the manuscript. Special thanks go to Assist Prof. Dr. Zubair Aslam, Assis. Prof. Dr. Zulfiquar A. Saqib and Assist. Prof. Dr. Safdar Bashir for reviewing of this paper.

\section{Competing Interests}

The author declares that he has no competing interests.

\section{References}

Açıkbaş, B. and Bellitürk, K., 2016. Effects of Vermicompost on Nutrient Contents of Trakya Ilkeren/5BB Grafting Combination Grapevine Saplings. Journal of Tekirdag Agricultural Faculty, 13 (4): 131-138.

Açıkbaş, B. and Bellitürk, K., 2017. Vermicompost Affects Shoot Growth of Trakya Ilkeren/5BB Grafting Combination Grapevine (Vitis vinifera L.) Saplings. International Congress of the New Approaches and Technologies for Sustainable Development, 21-24 September, 2017, Isparta, Turkey, Proceeding Book-II, pp.8795 .

Arancon, N.Q and Edwards, C.A., 2011. The Use of Vermicomposts as soil Amendments for Production of Field Crops (Edited by C.A. Edwards, N.Q. Arancon and R. Sherman), CRC Press, Chapter 10: 129-152.

Austin, P.D., 2015. Evaluation of Vermicompost as a fast-acting Nitrogen Amendment to Mitigate Nitrogen Deficiencies in Organic Vegetable Production. MS Thesis, University of Vermont.

Barlas, N.T. and Bellitürk, K., 2017. The Importance of Vermicompost on Converting Fertilization System from Chemical to Organic in Turkey. International Symposium on EuroAsian Biodiversity (SEAB-2017), Minsk, Belarus, 05-08 July, 2017, pp. 129.

Bellitürk, K. ve M.T. Sağlam, 2005. A Research on the Urea Hydrolysis Rate in the Soils of Turkey. Pakistan Journal of Biological Sciences. 8 (3): 446-449.

Bellitürk, K., Shrestha, P. and Görres, J.H., 2015. The Importance of Phytoremediation of Heavy Metal Contaminated Soil Using Vermicompost for Sustainable Agriculture. Journal of Rice Research, 3 (2), 6: e114.

Bellitürk, K., Görres, J.H., Kunkle, J. and M. Ryan, D.S., 2015. Can Commercial Mulches be Reservoirs of Invasive Earthworms? Promotion of Ligninolytic Enzyme Activity and Survival of Amynthas agrestis (Goto and Hatai, 1899), Applied Soil Ecology, 87 (2015) 27-31.

Bellitürk, K., 2016. Vermicomposting Technology for Solid Waste Management in Sustainable Agricultural Production. Çukurova J. Agric. Food Sci. 31 (3): 1-5.

Bellitürk, K. and Bağdatlı, M.C., 2016. Turkish Agricultural Soils and Population. Editorial. Agricultural Research \& Technology: Open Access Journal. 1 (2): ARTOAJ.MS.ID.555557.

Bellitürk, K., 2017. New Developments in Agricultural Resource Management: The Case of Vermicompost and its Some Applications in Turkey. International Conference: Advances in Agricultural Resource Management (ICARM-2017), April 5-7, University of Agriculture Faisalabad, Pakistan, pp. 19. 
Bellitürk, K., Hınıslı, N. and Adiloğlu, A., 2017a. The Effect of Vermicompost, Sheep Manure, and Cow Manure on Nutrition Content of Curly Lettuce (Lactuca sativa var.). Fresenius Environmental Bulletin (FEB), 26 (1a): 1116-1120.

Bellitürk, K., Adiloğlu, S., Solmaz, Y., Zahmacioğlu, A. and Adiloğlu, A., 2017b. Effects of Increasing Doses of Vermicompost Applications on Phosphorus and Potassium Concentrations of Pepper (Capsicum annuum L.) and Eggplant (Solanum melongena L.). Journal of Advanced Agricultural Technologies. 4 (4): 372-375.

Bellitürk, K., 2018. Some Evaluations about Use of Vermicompost in Agricultural Activity of Thrace Region, Turkey: A Review. Journal of Rice Research, 6 (2): 1000193.

Bhatnagar, R.K. and Palta, R.K., 1996. Earthworm-Vermiculture and Vermicomposting. Kalyani Publishers, New Delhi.

Bidabadi, S.S., Afazel, M. and Poodeh, S.D., 2016. The Effect of Vermicompost Leachate on Morphological, Physiological and Biochemical Indices of Stevia rebaudiana Bertoni in a Soilless Culture System. Int. J. Recycle Org. Waste Agric. 5: 251-262.

Bouche, M.M., 1977. Strategies Lombriciennes, Ecol. Bull. 25: 122-132.

Brown, G.G., 1995. How Do Earthworms Affect Microfloral and Faunal Community Diversity? Plant Soil 170: 209-231.

Dominguez, J., Edwards, C.A. and Subler, S., 1997. A Comparison of Vermicomposting and Composting Methods to Process Animal Wastes. Biocycle 38: 57-79.

Dominguez, J., 2004. State of the Art and New Perspectives on Vermicomposting Research. In: C.A. Edwards (Ed.). Earthworm Ecology (2 ${ }^{\text {nd }}$ Edition). CRC Press, LLC. pp. 401-424.

Edwards, C.A., 1995. Historical Overview of Vermicomposting. Biocycle, 36, 56-58.

Edwards, C.A., 2011a. Medium-and High-Technology Vermicomposting Systems. Vermiculture Technology: Earthworms, Organic Wastes and Environmental Management (Edited by C.A. Edwards, N.Q. Arancon and R. Sherman), CRC Press, Chapter 8: 91-102.

Edwards, C.A., 2011b. Low-Technology Vermicomposting Systems. Vermiculture Technology: Earthworms, Organic Wastes and Environmental Management (Edited by C.A. Edwards, N.Q. Arancon and R. Sherman), CRC Press, Chapter 7: 79-90.

Erdil, A. and Bellitürk, K., 2017. The Assessment of Sheep Manure as Vermicompost. International $8^{\text {th }}$ Balkan Animal Science Conference, BALNIMALCON 2017, 6-8 September 2017, pp. 72, Prizren, Kosovo.

Görres, J.H. and Bellitürk, K., 2012. Balancing Vermicomposting Benefits with Conservation of Soil and Ecosystems at Risk of Earthworm Invasions. VIII. International Soil Science Congress "Land Degradataion and Challenges in Sustainable Soil Management”, 15-17 May, 2012, Izmir, Turkey, Volume: 4, pp. 302-306.

Guerrero, R.D., 2009. Commercial Vermimeal Production: Is it Feasible? In: Guerrero, R.D., Eds., Vermi Technologies for Developing Countries. Proceedings of the International Symposium-Workshop on Vermi Technologies for Developing Countries, Los Baños, 16-18 November 2005, 112-120.

James, S.W. and Guimaraes, A., 2011. Discovery and Development of New Species for Vermiculture. Vermiculture Technology: Earthworms, Organic Wastes and Environmental Manag. (Ed. by C.A. Edwards, N.Q. Arancon, R. Sherman), CRC Press, Chapter 4: 41-52.

Karmakar, S., Brahmachari, K., Gangopadhyay, A. and Choudhury, S.R., 2012. Recycling of Different Available Organic Wastes throuhg Vermicomposting. E-Journal of Chemistry, 9 (2): 801-806.

Mengistu, T., Gebrekidan, H., Kibret, K., Woldetsadik, K., Shimelis, B. and Yadav, H., 2017. The Integrated Use of Excreta-based Vermicompost and Inorganic NP Fertilizer on Tomato (Solanum lycopersicum L.) Fruit Yield, Quality and Soil Fertility. International Journal of Recycling Organic Waste Agriculture, 6 (1): 63-77. 
Noble, R. and Coventry, E., 2005. Suppression of Soil-Borne Plant Diseases with Composts: A Review. Biocontrol Science and Technology 15, 3-20.

Patil, S.S., Kasture, M.C. and Dhopavkar, R.V., 2018. Micro-nutrient Enriched Vermicompost by Coconut Coir Waste. Int. J. Curr. Microbiol. App. Sci. 7 (06): 2352-2361.

Sinha, R.K., Agarwal, S., Chauhan, K. and Valani, D., 2010. The Wonders of Earthworms \& its Vermicompost in Farm Production: Charles Darwin's "Friends of Farmers", with Potential to Replace Destructive Chemical Fertilizers from Agriculture. Agricultural Sciences, 1 (2): 76-94.

Sun, B., Zhang, L., Yang, L., Zhang, F., Norse, D. and Zhu, Z., 2012. Agricultural Non-point Source Pollution in China: Causes and Mitigation Measures. Ambio 41 (4): 370-379.

Sutton, M.A., Howard, C.Mm., Erisman, J.Q., Billen, J., Bleeker, A., Greenfelt, P., van Grinsven, H. and Grizzetti, B., 2011. The European Nitrogen Assessment, Sources, Effects and Policy Perspectives. Cambridge University Press, Cambridge.

Vivas, A., Moreno, B., Garcia-Rodriguez, S. and Benitez, E., 2009. Assessing the Impact of Composting and Vermicomposting on Bacterial Commonity Size and Structure, and Microbial Functional Diversity of an Olivemill Waste. Bioresource Technology, 100, 1319-1326.

Yan, Y.W., Nor Azwady, A.A., Shamsuddin, Z.H., Muskhazli, M., Aziz, S.A. and Teng, S.K., 2013. Comparison of Plant Nutrient Contents in Vermicompost from Selected Plant Residues. African Journal of Biotechnology, 12 (17): 2207-2214.

Y1lmaz, K. and Bellitürk, K., 2018. Vermicomposting of Horse Dung Using Eisenia foetida (Sav.). International Agricultural Science Congress, 9-12 May 2018, pp. 151, Van/Turkey.

Zahmacıŏlu, A., Ahi, Y. and Bellitürk, K., 2017. Determination of Vermicompost and Ammonium Nitrate Applications Effectiveness on Broccoli with Soil and Leaf Analysis. VIII. International Scientific Agriculture Symposium (Agrosym 2017), Jahorina, October 5-8, 2017, pp. 1660-1665.

Submitted: 30.10 .2018

Accepted: 12.12.2018 